\title{
Building specialized dictionaries using lexical functions
}

\author{
Jeanne Dancette \& Marie-Claude L'Homme
}

Université de Montréal

It is now widely acknowledged that terms enter into a variety of structures and that classic taxonomies and meronymies represent only a small part of the relationships terms share. This can be seen in recent specialized dictionaries that account for derivational relationships, co-occurrents, synonyms, antonyms, etc. It also has been underlined in several articles written by terminologists as well as linguists or computational scientists working with specialized corpora. This article will discuss the advantages and shortcomings of trying to account for semantic relations between terms using a specific framework, i.e. lexical functions (Mel'čuk et al. 1984-1999, 1995). It is based on a long-term project aimed at converting an existing paper dictionary (Dancette \& Réthoré 2000) into a relational database. We will show that even if lexical functions have several advantages, a number of decisions must be made to accommodate the description of specialized terms.

\section{Introduction}

In this article, we would like to summarize the different insights brought by a research project aimed at representing a wide variety of semantic relationships between terms using a formal lexico-semantic framework called Explanatory and Combinatorial Lexicology (ECL) (Mel'čuk et al. 1984-1999, 1995). The framework was used in order to assist terminographers during the process of converting a printed dictionary (Dancette \& Réthoré 2000) into a relational database. The original specialized dictionary is bilingual (English-French) and deals with terms pertaining to the field of retailing. It is described briefly in section 2 .

These insights, even though they have been supplied by a specific project, shed some light on fundamental and applied issues related to the description of terms and terminological relationships in specialized dictionaries. It is now widely acknowledged that terms enter into a variety of semantic relationships with other lexical units. These relationships can be hierarchical, as those shared by a hyperonym and its hyponyms, or non-hierarchical, as those shared by cause and effect relationships or by noun and verbal collocations.

The traditional methodologies for describing terms - placing the concept at the centre of the analysis and trying to account for the organization of knowledge - have led terminologists to focus on taxonomic and meronymic relationships and to overlook an entire set of relevant relationships. During the past decade terminologists have started to question 
the adequacy of these methodologies for describing terms and have turned to alternative descriptive models such as those supplied within the field of lexicology. Attempts at describing relationships between terms using lexico-semantic frameworks, which were scarce only a decade ago, are now becoming widespread. Several authors have claimed that descriptions should rely more heavily on linguistic models (e.g. Frawley 1988; Jousse \& Bouveret 2003, also, refer to L'Homme forthcoming, for a review). Some have even been implemented in commercial dictionaries (Binon et al. 2000; Cohen 1986; Dancette \& Réthoré 2000).

In this article, one question will hold our attention: Should terminologists try to capture the organization of knowledge in specialized subject fields using terms as linguistic representations of this knowledge or should they account for lexical units with specific meanings? The answer has important implications on the ways in which terms and relationships between terms are envisaged.

Traditionally, the focus on the organization of knowledge (or conceptual approach) would lead to consider a limited set of relationships, mainly logical, or hierarchical. However, the focus on meanings that we have adopted from the start has led us to adhere to a lexico-semantic approach and to consider the wide variety of relationships into which terms enter. In the course of the conversion of the dictionary of retailing, we had to deal with the two approaches simultaneously. If the printed dictionary was originally compiled according to a conceptual approach, it also includes information, such as collocates or derivations, that is not always present in terminological dictionaries.

This is why we chose to convert it using ECL, which is a framework based on the senses of lexical units. Our work shows that it is practically feasible to combine conceptual and lexico-semantic approaches. However, even if we adopted the ECL approach, and more precisely its mechanism for capturing lexical relationships, i.e. lexical functions (LFs), a number of pragmatic factors led us to distance ourselves from the original model. In this paper, the term lexical function $(L F)$ refers to the functions developed in the original model whereas the term lexicosemantic relation $(L S R)$ to the final implementation as it will be found in the electronic dictionary of retailing.

This article is divided into four sections. Section 2 describes very briefly the printed dictionary, which served as a basis for this project and the general layout of the relational database into which it has been imported. In section 3, we explain why lexical functions (LFs) were chosen for systematically capturing the multiple relationships between terms. In the main part of the article (section 4), we will present a few results and explain the choices we made. In doing so, we will show why and how we distanced ourselves from the original LF model and adapted it to capture relationships that appeared central in the field of retailing but that were not taken into account in LF formalism. Finally, section 5 will sum up the problems we encountered and will provide a discussion on future 
directions for terminology. A list of lexical functions cited in the article with their explanation is given in Appendix B. The revised list, called $L S R$ s, is given in Appendix C.

\section{Brief presentation of the dictionary (paper and electronic)}

The Dictionnaire analytique de la distribution / Analytical Dictionary of Retailing (Dancette \& Réthoré 2000) is intended for translators as well as professors, students and professionals in business and distribution trades. It targets two main objectives: to list the largest possible number of terms and to present them in a manner that facilitates the comprehension of concepts to the maximum.

The dictionary is structured around 350 key concepts related to shopping centres, marketing, shop layout, etc. These key concepts are described with a keen effort to highlight the semantic relationships linking the terms and to explain the nuances in meanings and regional differences in usage. The articles of the dictionary of retailing are written as short encyclopaedic texts in a language that is far from formal. Phraseological variations have been favoured over regularity and systematicity of expression.

In addition to the 350 full-fledged articles (the main body of the dictionary), the dictionary includes a lexicon of some 3500 French and English related terms, covered in the body of the 350 articles.

Each entry is divided into nine parts (an example has been reproduced in Appendix A):

1. The English main headword and its synonyms followed by grammatical information and usage marks;

2. The French equivalent terms;

3. A French definition;

4. Semantic precisions;

5. Semantic relationships between the terms belonging to a single field;

6. Additional information providing extralinguistic information (historical notes or pragmatic information);

7. Linguistic information;

8. An English and a French context;

9. Examples.

The contents of the printed dictionary were placed in a relational database. The nine headings have been distributed in five different tables. The first two tables contain linguistic data related to the English and French terms respectively; the third table contains the definitions; the fourth table is used to store the data on contexts. The clear separation of the linguistic and semantic data (i.e. the terms and contexts on one side, and the definition on the other) allows for a flexible integration of other lan- 
guages without having to redesign the core of the entry. Finally, the fifth table contains the data on semantic relationships. Figure 1 shows how the relationships between the tables are established. Figure 2 shows a concrete example of this implementation.

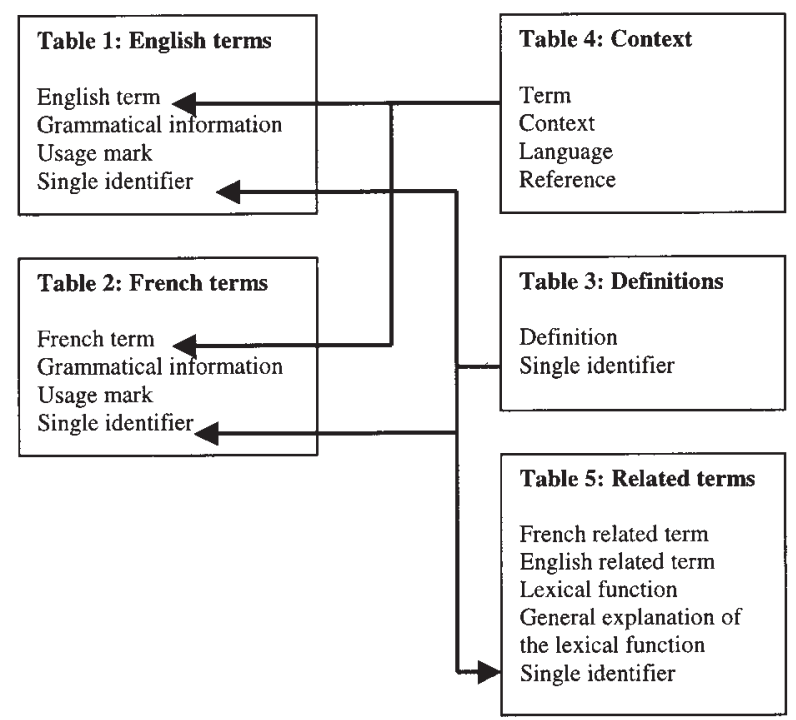

Figure 1: structure of the relational database

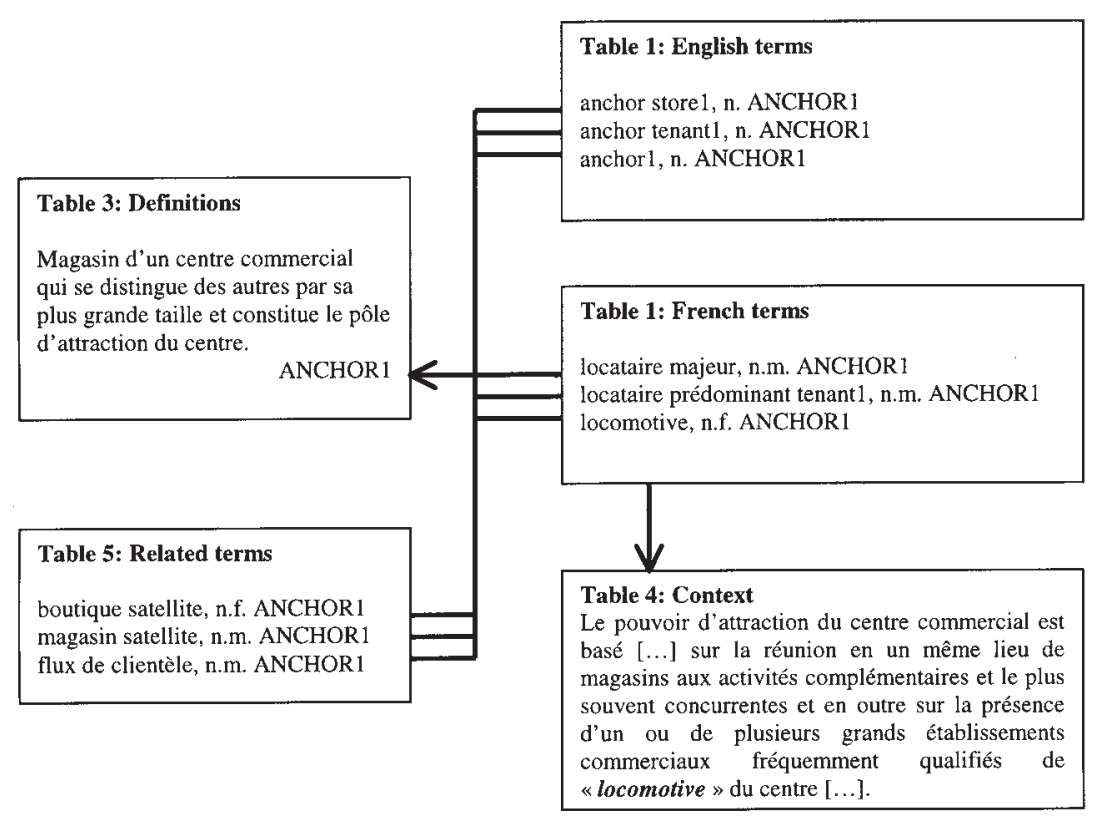

Figure 2: part of the article ANCHOR 


\section{Dealing with various semantic relationships}

As can be seen in Appendix A, various semantic relationships between the headword and other terms that belong to the field of retailing are explained throughout the article, especially under the headings Definition, Semantic precisions and Internotional Semantic relations. The relationships can be classified as:

- hyperonymy and hyponymy: e.g. VENTE AUX ENCHÈRES (Engl. AUCTION): ENCHÈre AU RABAIS (Engl. DutCh AUCTION): ENCHÈre (Engl. BID): FOLLE ENCHÈRE (Engl. FALSE BIDDING);

- true synonymy: e.g. VENTE AUX ENCHÈRES: VENTE À LA CRIÉE (Engl. AUCTION: AUCTION SALE);

- agents involved in a process: VENTE AUX ENCHÈRES (Engl. AUCTION): COMMISSAIRE-PRISEUR (Engl. AUCTIONEER): ENCHÈRE (Engl. BID): ENCHÉRISSEUR (Engl. BIDDER);

- other actants or circumstants, such as a typical localization: VENTE AUX ENCHÈRES (Engl. AUCTION): SALLE DE VENTE AUX ENCHÈRES (Engl. AUCTION ROOM);

- meanings expressed by terms pertaining to different parts of speech: ENCHÈRE (Engl. BID): ENCHÉRIR (Engl. TO BID);

- syntagmatic relationships such as verbal collocations: PROCÉDER AUX ENCHÈRES (TO HOLD AN AUCTION).

Other relationships such as quasi-synonymy, co-hyponymy, meronymy and antonymy are to be found throughout the dictionary. They are not only mentioned, but explained extensively in natural language and with a variety of formulations. When incorporating this information in the relational database, we wanted to systematize the explanations without losing their expressiveness. Lexical functions (Mel'čuk et al. 1984-1999, 1995) appeared to be the best solution in this respect. In the following subsection, we will present lexical functions and further explain their interest in accounting for the semantic relationships in the specialized dictionary on retailing.

\subsection{Why lexical functions?}

A lexical function (LF) is designed to capture a general, abstract and recurrent sense in different languages. It is written $\mathbf{f}(\mathrm{x})=\mathrm{y}$ with $\mathbf{f}$ representing the function, $\mathrm{x}$ the argument (or keyword), and $\mathrm{y}$ the value expressed by the function when applied to a given argument. The meaning associated with an LF can produce a relatively high number of values. For example, Magn is a function that expresses an intensification. It can be applied to different lexical units and produce a high set of values (e.g. Magn(smoker) = heavy; Magn(bachelor) = confirmed, etc.) (Mel'čuk et al. 1995: 126-127). 
Lexical functions have been used to account for semantic relationships in general dictionaries (e.g. Fontenelle 1997; Mel'čuk et al. 19841999) and their importance for terminology has been examined by various authors (Cohen 1986; Frawley 1988; Jousse \& Bouveret 2003; L'Homme 2002, 2004).

LFs were chosen in our project for the following reasons:

- The model is relational and is thus formally compatible with our database.

- They capture a large set of senses. There are approximately 60 standard LFs (Mel'čuk et al 1995; Wanner 1996).

- Different semantic relations - paradigmatic and syntagmatic relations can be accounted for with the same apparatus.

- The same sense is described with the same LF. This enables us to overcome the stylistic variety of the printed dictionary.

- LFs can be further explained in a more transparent way for users (Polguère 2003).

\subsection{Assigning lexical functions to terms: methodological choices and initial problems}

When converting the semantic relationships explained in the printed dictionary, a number of methodological choices had to be made. We will illustrate a first one with the example cited above, i.e. the AUCTION entry. A close look at the article reveals that the French term ENCHÈRE has two different senses (in English, two different terms are used for each sense, AUCTION and BID). LFs are assigned separately to each sense as shown in Table 1. Other relevant lexical functions and their explanations are provided in Appendix B.

\begin{tabular}{|l|l|l|l|}
\hline ENCHÈRE 1 & AUCTION & ENCHÈRE 2 & BID \\
\hline Syn: VENTE AUX ENCHÈRES & & Syn: OFFRE & \\
\hline $\mathrm{S}_{1}$ : COMMISSAIRE-PRISEUR & AUCTIONEER & $\mathrm{S}_{1}$ : ENCHÉRISSEUR & BIDDER \\
\hline Oper $_{1}:$ PROCÉDER À & to HOLD AN AUCTION & $\mathrm{V}_{0}$ : enchérir & to BID \\
\hline $\mathrm{S}_{\text {loc }}:$ SALLE DE VENTE & AUCTION ROOM & $\begin{array}{l}\text { Magn + AntiVer: } \\
\text { FOLLE ENCHÈRE }\end{array}$ & FALSE BID \\
\hline & $\begin{array}{l}\text { Magn + AntiVerS } \\
\text { FOL ENCHÉRISSEUR }\end{array}$ & FALSE BIDDER \\
\hline
\end{tabular}

Table 1: lexical functions assigned to two different senses of enchère

Similar problems have been encountered with articles dealing with verb nominalizations, which can convey a meaning of activity or a meaning of result. Theses senses had to be clearly separated before LFs could be assigned. 
Also, since the original dictionary was not compiled according to a lexico-semantic approach, key information is lacking. For example, several terms that appear in the articles are not described in a separate entry. Also, since the focus was placed on noun terms (nouns or noun phrases), many related verbs or adjectives are missing (e.g. FRANCHISAGE (Engl. FRANCHISING) was encoded but not FRANCHISER (Engl. TO FRANCHISE)). More fundamentally, the actantial structure of terms was not clearly indicated, but the assignment of several LFs requires this type of information.

Another problem was caused by the fact that several entries are complex nouns with a compositional meaning. Although this is a current practice in terminological dictionaries, it posed difficulties in the assignment of LFs. For example, an entry is devoted to the complex term BIEN DURABLE (Engl. DURABLE GOOD) and another to the generic term BIEN (Engl. GOOD). We chose to account for paradigmatic relationships such as those existing between BIEN DURABLE and BIEN with the function Gener. However, if we had applied the principles of ECL, we would have described the syntagmatic relationship between BIEN and DURABLE with the function Magn ${ }^{\text {Temp }}$.

Finally, many terms highlighted in the dictionary share a semantic relation that could not be accounted for in terms of lexical functions.

\section{Results}

Related terms (in bold in the printed dictionary) were scrutinized as potential lexico-semantic relations (LSRs) as often as they occurred in the different articles of the dictionary. Because their relation with each headword had been examined, we were able to detect and correct inconsistencies in the attribution of LSRs. A total of 28 different functions were used. This number was deemed sufficient and necessary to account for the relationships between the terms that carry the most important information on concepts referred to in the dictionary. However, as we will see in the following sections, the assignment of some of the original lexical functions (LFs) was modified. Firstly, some LFs were simplified (i.e. we chose to generalize some fine-grained distinctions expressed by LFs because we did not have enough occurrences to justify their use). Secondly, other functions were created to capture relationships not accounted for in the original model (e.g. relationships that are central in terminological descriptions but that ECL would not consider relevant for lexical units). We discuss three classes of LSRs: 1) classic relationships in terminology: synonyms, antonyms, taxonomic and meronymic relationships; 2) actantial and circumstantial relationships (both categories are paradigmatic relationships with nominal forms); and 3) syntagmatic and derivational relationships. 


\subsection{Synonyms, antonyms, taxonomic and meronymic relationships}

These typical terminological relations correspond in the original LF model to Gener, Syn (and other types of synynony, e.g. $\mathbf{S y n} \mathbf{n}_{n}$ ), Anti and Contr. We used the main distinctions made within the FL model, but made some important adaptations to the data contained in our dictionary:

- Gener proved very useful but following Grimes (1990), we felt a strong need to add the function Spec, extremely productive in taxonomic series to list the different specific terms that are linked to an entity (e.g. SPECIALTY CENTER, FACTORY-OUTLET CENTER, MEGAMALL are described as Specs of SHOPPING CENTER). This decision is partly linked to our methodological choice to consider most adjectives as parts of complex nouns. For example, DUTCH AUCTION (FR.: VENTE AUX ECHÈRES, VENTE SOUS-ECHÈRES is semi-compositional. Hence, it would not be possible to describe this noun phrase under the entry.

- The standard practice in specialized dictionaries is to list all true synonyms as headwords. In the electronic version, all synonyms are linked to the definition. Other terms share a number of semantic features but not all. These are represented using lexical functions such as Anti, Conv, $\mathbf{S y n}_{\cap}$ and Contr. Departing from the LFs in the ECL model, we used the label Contrast for all terms that oppose one another by one feature but share with it all other features; and we used the function $\mathbf{S y n}_{\text {use }}$ for all the terms that refer to the same reality but consider it from a different point of view, depending on the use or usage of the term.

Thus, BIEN DURABle (Engl. DURABle GOOD) is opposed to BIEN NON DURABLE (Engl. NON-DURABLE GOOD) and BIEN SEMI-DURABLE (Engl. SEMI-DURABLE GOOD) according to the durability of the product. Consequently, these terms are labelled contrastives (Contrast).

On the other hand, CENTRE DE BOUTIQUES SPÉCIALISÉES (Engl. SPECIALTY CENTER) is considered a variant of CENTRE HAUT DE GAMME (Engl. UPSCALE CENTER) as it refers to the same reality but from a different angle. The two terms are labelled $\mathbf{S y n}_{\mathbf{u s e}}$, meaning synonyms with variations in use.

In our corpus, the LSR Contrast proved as productive as the LSR $\mathbf{S y n}_{\text {use }}$. This should come as no surprise. A specialized dictionary has as its main objective to shed light on each distinct entity and to distinguish the nuances of meaning between terms. We identified the function Contrast in each sentence saying or meaning " $\mathrm{X}$ opposes $\mathrm{Y}$ by the feature A". Regrouping and degrouping all the terms entering into an opposition relationship on the paradigmatic level was part of our terminological methodology.

- Finally, a number of meronymic relationships were taken into account in our dictionary. We first used the original LFs Mult ("group of") and 
Sing ("an element within a group") to capture relationships such as those shared by the terms CLIENT (Engl. CUSTOMER) and CLIENTÈLE (Engl. CLIENTELE). We also resorted to other functions to capture different types of meronymic relationships. The function Part was added, as suggested by Fontenelle (1997) to represent relationships shared by parts and wholes (e.g. CASH REGISTER is described as a part of CHECKout counter). We also created its opposite function Tot. Phase was also added in order to account for the chronological phases in a process (Dancette \& L'Homme 2002) (e.g. GROWTH is a phase in a PRODUCT LIFE CYCLE).

\subsection{Argumental and circumstantial relationships}

A number of relationships involved predicates and their arguments. In the original LF model arguments are noted according to their position $\left(\mathbf{S}_{1}\right.$, $\mathbf{S}_{2}, \mathbf{S}_{3}$, etc.) and circumstants as $\mathbf{S}_{\text {res }}, \mathbf{S}_{\text {loc }}$, but we opted for a more systematic and transparent notation for potential users of our dictionary. For instance, the predicative term CONCESSION DE LICENCE (Engl. LICENSING) calls for the arguments LICENCE (Engl. LICENSE), CONCÉDANT (Engl. LICENSOR), LICENCIÉ (Engl. LICENSEE). In our model, however, LICENSE is noted 'object aimed at' (Obj); LICENSOR is identified as 'agent' (Ag) and LICENSEE as 'recipient' (Recip) of LICENSING. Even though our interpretation of senses complies with the original model, we opted for different notations.

Also, a number of circumstantial relationships were found in the dictionary. The following example illustrates the need to look for such relationships. The predicative term MARQUE (Engl. BRAND) has PRODUIT (Engl. PRODUCT) and NOM DE MARQUE (Engl. BRANDNAME) (or LOGO, or BRANDMARK) as arguments. But the term FIDÉLITÉ À LA MARQUE (Engl. BRAND LOYALTY) found in the same article does not have an argumental role. Other examples of argumental and circumstantial relationships described in the dictionary are given below:

$\operatorname{Ag}($ FRANCHISAGE $)=$ FRANCHISEUR (Engl. FRANCHISING; FRANCHISOR)

Instr(TERMINAL DE PAIEMENT ÉLECTRONIQUE) = CARTE MAGNÉTIQUE (Engl. ELECTRONIC PAYMENT TERMINAL; MAGNETIC CARD)

Med(PUBLIPOSTAGE) $=$ FEUILLET $($ Engl. DIRECT MAIL ADVERTISING; FLYER)

Loc $($ COUPONNAGE ÉLECTRONIQUE) = SITE INTERNET (Engl. ELECTRONIC COUPONING; WEB SITE)

\subsection{Other relationships: properties, units of measure, utility}

A number of LSRs were assigned in a way that differs substantially from the original LFs. Doing this, we comply to the more traditional view of relationships in terminology: the expressions given as values point to 
some important information on the concept (i.e. prototypical properties); they do not rely on argumental roles.

The function Prop (property) illustrates this point. It was conceived to retrieve the terms expressing the technical features attached to the definition of a concept, as illustrated by Sager's example (1990: 34): "compressibility is a property of gas". In our corpus, sentences expressing this relationship in such a clear way are scarce, and the function Prop proved complex and rarely directly marked. Consequently, we relied, in many cases, on the expert knowledge of the concept more than on linguistic markers (see Dancette \& Halimi 2004, for more details.) In our field, experts say that 'products' are identified by the following intrinsic properties: PRICE, BRAND, LIFECYCLE, PRODUCT DIFFERENTIATION, PROFITABILITY, MARKETSHARE. Similarly, 'point of sale' is identified by: ASSORTMENT, SERVICE, PULLING POWER, PRICE POLICY. Here are some examples:

Prop $($ ASSORTMENT $)=$ DEPTH/SHALLOWNESS, or LOW DEPTH; BREADTH/NARROWNESS; LENGTH/SHORTNESS

Prop $($ CASHCOW $)=($ HIGH $)$ PROFITABILITY

$\operatorname{Prop}(\mathrm{DOG})=($ LOW $)$ PROFITABILITY

$\operatorname{Prop}($ CATEGORY KILLER $)=$ SELF-SERVICE

Prop $($ DEPARTMENT STORE $)=($ VERY WIDE $)$ ASSORTMENT

Other examples of conceptual relationships are: units of measure (Mes), Caus, Fonct and result (Result).

Mes(FRONTALE $)=$ UNITÉ DE VENTE

Result(VOL À L'ÉTALAGE) = PERTE, ÉCART D'INVENTAIRE

Caus(COMMANDE EN SOUFFRANCE) = RUPTURE DE STOCK (Engl. INVENTORY SHORTAGE)

Fonct $($ MARCHANDISEUR $)=$ ASSORTIMENT $($ Engl. ASSORTMENT $)$

\subsection{Relationships between nouns and other parts of speech}

As expected, these proved much less productive than the paradigmatic relations described in the previous sections.

\subsubsection{Relationships with verbs}

Especially for verbs, the FL sophistication was deliberately discarded. Verbs were grouped in three categories, i.e. derivations (ENCHÈRES $\Rightarrow$ enchérir; $\mathrm{BID} \Rightarrow$ to bid; ÉTIQUETTE $\Rightarrow$ étiqueter); direct collocative verbs (ENSEIGNE $\Rightarrow$ développer l'enseigne, BANNER $\Rightarrow$ to develop the banner; SHOP $\Rightarrow$ to set up shop, BANNIÈRE $\Rightarrow$ implanter l'enseigne); associated actions, i.e. verbs for typical actions related to a concept (ENCHÈRE $\Rightarrow$ adjuger, AUCTION $\Rightarrow$ to knock down, to strike off). This simplification was 
deemed adequate because the user of the dictionary is expected to rely on his/her linguistic ability, as opposed to the ECL model, which may be used for encoding purposes.

\subsubsection{Relationships with adjectives and adverbs}

Only a few adjectives and adverbs appeared as true headwords (e.g. ACHALANDÉ (Engl. WELl PATRONIZED), AFFILIÉ (Engl. AFFILIATED), BON MARCHÉ (Engl. LOW-COST, INEXPENSIVE), HAUT DE GAMME (Engl. HIGH-END, UPMARKET), PROMOTIONNEL (Engl. PROMOTIONAL), etc. As mentioned above, most adjectives entering into the composition of complex nouns were discarded in order to highlight paradigmatic relations rather than syntagmatic ones.

The criteria we used is the indissociability of the term. Thus, if DURABLE associates only with GOODS or PRODUCT; then DURABLE GOODS is considered a lexical unit, as opposed to ACHALANDÉ (Engl. WELL PATRONIZED), or APPROVISIONNÉ (Engl. WELL-STOCKED), which associate with a larger number of nouns.

It can even be argued that many adjectives such as DUTCH in DUTCH AUCTION Or CHINESE in CHINESE AUCTION, DURABLE in DURABLE GOODS, BANAL in BIEN BANAL, DIRECT in DIRECT MARKETING take on specialized meanings when they are in association with a few extremely specific nominal bases.

Also, we found that the adjective is a highly unstable part of the term in the vocabulary of retailing, and that many synonyms can associate with the same term (e.g. DIRECT MARKETING is synonymous with DIALOGUE MARKETING, PERSONAL MARKETING, DATABASE MARKETING, RELATIONSHIP MARKETING). Treating the adjectives as terms would have led to an explosion of the category without adding informational value. Furthermore, the lexicalization of adjectival forms is an unequal process when we compare pairs of languages. For example, English has the adjectives ANCHORLESS, ANCHORED, but French does not; and therefore unstable periphrases are used.

\section{Concluding remarks}

Converting a terminological dictionary in electronic form enabled us to highlight some differences between the encoding of semantic relationships shared by terms in a terminological setting and the same encoding but viewed in a lexicographic framework. Of course, we referred to an extremely specific lexical framework, ECL, but much of what has been said above would apply to other formal models, at least as far as our comparison with terminology is concerned.

It would seem that the description of lexical units related to a special subject field requires that a choice be made between the conceptual 
approach and the linguistic approach. Even if we tried to combine the two approaches, we had to discard many lexical features, and syntagmatic relations were not systematically looked for. In addition, many methodological decisions had to be made in order to accommodate the data under analysis.

However, the ECL model of lexical functions helped us to retrieve more relationships than classic terminological approaches. FLs are closely linked to the linguistic definition of the headword with the identification of all its actants. Furthermore, the distinctions of senses are based on the linguistic behaviour of lexical units, which will then be treated separately. On the other hand, terminological definitions try to answer questions on the nature of things (what, where, when, how, for what purpose, etc.). But we encounter a new problem here: commercial entities are culture-dependent and their descriptions or definitions vary accordingly. For example, in North America, a post office is often located in a drugstore; therefore the relation part(drugstore)=post office is possible in some cases. If a lexical approach can help reduce the imprecision of definitions, assigning semantic relations is very often risky, because of fuzziness. It would have been impossible in some instances without the expert knowledge in the field of retailing. In such cases, the syntactic forms of the sentences were less reliable than encyclopaedic knowledge.

As a conclusion, we found that LFs appear to be a very helpful tool for capturing semantic relationships between terms. They could help enrich terminological descriptions and offer a means to better interpret relationships between terms. We clearly think that combining terminological and lexicological traditions helps to understand different facets of terms and concepts. Starting a new dictionary using a combined approach in a systematic manner would be beneficial and offer new perspectives for terminographic projects.

\section{Bibliography}

Binon et al. (2000). Dictionnaire d'apprentissage du français des affaires, Paris: Didier.

Cohen, C. (1986). Lexique de cooccurrents - Bourse et conjoncture économique, Brossard (Québec): Linguatech.

Cruse, D.A. (1986). Lexical Semantics, Cambridge: Cambridge University Press.

Dancette, J. (1998). "Le potentiel du dictionnaire spécialisé bilingue électronique." Fontenelle, T., P. Hillissman, A. Michiels et al. (eds.) EURALEX 1998. Proceedings, Liège: University of Liège, 387-396.

Dancette, J. \& Halimi (2004). "Repérage des relations lexico-sémantiques dans un dictionnaire de la distribution; bilan d'une tentative de formalisation". Actes. Terminologie, ontologie et représentation des connaissances, Université Jean-Moulin, Lyon-3, 22-23 janvier 2004.

Dancette, J. \& M.C. L'Homme (2002). "The gate to knowledge in a multilingual specialized dictionary: Using lexical functions for taxomonic and 
menonymic relations." Proceedings. Euralex 2002, Copenhagen: University of Copenhagen, 597-606.

Dancette, J. \& C. Réthoré (2000). Dictionnaire analytique de la distribution; Analytical Dictionary of Retailing, Montréal, Presses universitaires de Montréal.

Fontenelle, T. (1997) . Turning a Bilingual Dictionary into a Lexical-Semantic Database, Tübingen: Max Niemeyer.

Frawley, W. (1988). "New forms of specialized dictionaries." International Journal of Lexicography 1(3), 189-213.

Grimes, J. (1990). "Inverse Lexical Functions." Steele, J. (ed.). Meaning-Text Theory: Linguistics, Lexicography and Implications, Ottawa: Ottawa University Press, 350-364.

Iris, M.A., B.E. Litowitz \& M. Evens (1988). "Problems of the part-whole relation." Evens, M.W. (ed.). Relational Models of the Lexicon. Representing Knowledge in Semantic Networks, Cambridge: Cambridge University Press, 261-288.

Jousse, A.L. \& M. Bouveret (2003). "Lexical functions to represent derivational relations in specialized dictionaries." Terminology 9(1), 71-98.

L'Homme, M.C. (2002). "Fonctions lexicales pour représenter les relations sémantiques entre termes." Traitement automatique des langues (TAL) 43(1), 19-41.

L'Homme, M.C. (2004). "Sélection des termes dans un dictionnaire d'informatique: comparaison de corpus et critères lexico-sémantiques." Euralex International Congress. Proceedings. Lorient (France), 583-593.

L'Homme, M.C. (forthcoming). "Using explanatory and combinatorial lexicology to describe terms." Wanner, L. (ed.). Selected Lexical and Grammatical Topics in the Meaning-Text Theory. In Honor of Igor Mel'čuk, Amsterdam/Philadelphia: John Benjamins.

L'Homme, M.C. \& J. Dancette (2001). "Modélisation des relations sémantiques dans un dictionnaire spécialisé bilingue." Clas, A., H. Awaiss \& J. Hardanne (eds.). L'Éloge de la différence: La voix de l'autre. VI Journées scientifiques de l'AUF, Beyrouth (Lebanon), 385-400.

Mel'čuk, I. (1998). "Collocations and Lexical Functions." In Cowie, A.P. (ed.), Phraseology. Theory, Practice and Applications, Oxford: Oxford University Press, 23-53.

Mel'čuk, I. et al. (1984-1999). Dictionnaire explicatif et combinatoire du français contemporain. Recherches lexico-sémantiques 1-IV, Montréal, Les Presses de l'Université de Montréal.

Mel'čuk I., A. Clas \& A. Polguère (1995). Introduction à la lexicologie explicative et combinatoire, Louvain-la-Neuve (Belgique), Duculot / Aupelf UREF.

Otman, G. (1996). Les représentations sémantiques en terminologie, Paris: Masson.

Polguère, A. (2003). "Collocation et fonctions lexicales: pour un modèle d'apprentissage", In Grossmann, F. \& A. Tutin (eds). Les collocations. Analyse et traitement, coll. Travaux et recherches en linguistique appliquée, Paris: Éditions de Werelt.

Sager, J.C. (1990). A Practical Course in Terminology Processing, Amsterdam/ Philadelphia: John Benjamins.

Temmerman, R. (2003). "Innovative methods in specialized lexicography." Terminology 9(1), 117-135.

Wanner, L. (ed.) (1996). Lexical Functions in Lexicography and Natural Language Processing, Amsterdam / Philadelphia: John Benjamins. 
Winston, M.E., R. Chaffin \& D. Herrman (1987). "A Taxonomy of part-whole relationships." Cognitive Science 11(4), 417-444. 


\section{Appendix A}

\section{AUCTION, AUCTION SALE, SALE BY AUCTION}

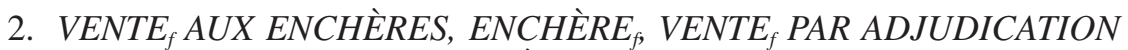
Voir VENTE AUX ENCHÈRES, ENCAN ${ }_{m}$ Voir VENTE AUX ENCHÈRES, VENTE $f$ À LA CRIÉEVoir VENTE AUX ENCHÈRES (Fr.)

3. Définition:

Processus de vente publique de biens ou titres de propriété aux plus offrants.

\section{Précisions sémantiques:}

Le commissaire-priseur (auctioneer) procède aux enchères qui se font à vive voix dans une salle de vente (auction room). Il présente l'article et demande une première offre (bid) ou annonce lui-même un prix initial minimal. Les acheteurs potentiels font des offres pour enchérir $\left(\right.$ bid $_{v}$, make $_{v} a$ bid), chaque offre étant supérieure à la précédente. Le commissaire-priseur

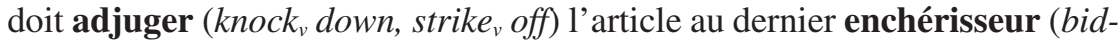
der). Si celui-ci n'est pas capable de payer la somme offerte, s'il a fait une folle enchère (false bidding), l'article sera revendu. Si le prix obtenu la deuxième fois est inférieur à celui de la folle enchère, le fol enchérisseur (false bidder) devra payer la différence.

Les objets pouvant être vendus aux enchères sont de nature et d'origine diverses. Il peut s'agir tant de meubles (bijoux, objets d'art, animaux) que d'immeubles. La vente aux enchères peut être volontaire de la part du vendeur ou forcée, par exemple à la suite d'une faillite ou d'une saisie.

Le gouvernement a aussi recours à la vente aux enchères pour disposer d'objets volés ou trouvés non réclamés, de biens saisis à la douane ou pour se débarrasser de biens en surplus.

La vente aux enchères est parfois utilisée sur le marché des bons du Trésor (treasury bills), sous le nom d'adjudication des bons du Trésor (treasury bill auction, bill auction é.-U. $_{\text {. }}$.

\section{Relations internotionnelles:}

Il existe quelques variantes de la vente aux enchères décrite plus haut.

Lors d'une enchère au rabais ou vente aux sous-enchères (Dutch auction, Chinese auction), le prix initial est fixé plus haut que le prix que l'on estime obtenir, pour ensuite être baissé jusqu'au moment où quelqu'un accepte le prix. Ce type d'enchères est utilisé, entre autres, dans la vente d'animaux (lifestock) et dans la vente de poissons et de produits agricoles dans le domaine du commerce de gros. 
Dans la forme la plus moderne, la vente au cadran ou marché au cadran (clock auction, clock auction sale), le processus est automatisé. Les acheteurs sont assis dans un amphithéâtre muni d'un grand cadran où les prix sont affichés. Les prix baissent jusqu'à ce qu'un acheteur arrête le mécanisme au moyen d'un bouton devant lui et fasse ainsi une offre. Si la marchandise est vendue en lots, le premier offrant peut choisir la quantité qu'il veut, et le reste sera vendu aux acheteurs subséquents.

Dans la \# (sealed bid auction), la vente n'est pas publique, mais les offres sont faites par écrit. L'objet sera adjugé au plus offrant.

Adjudication 1 (adjudication) est le terme légal pour la mise en vente aux enchères d'un bien. Le terme français signifie aussi la déclaration par laquelle le commissaire-priseur vend le bien au plus offrant. Il ne faut pas confondre ce terme avec son homonyme adjudication 2 (tender), qui désigne une soumission dans le cadre d'un appel d'offres. Le terme anglais tender peut aussi renvoyer à une offre d'achat, comme dans l'expression vente par adjudication ou vente par soumission (sale by tender). (sale by tender)

t.c. vente par appel d'offres, vente à l'encan, vente à l'enchère

On appelle aussi vente à la criée ou criée (\#) la méthode de vente dans les marchés publics où les exposants interpellent les consommateurs.

\section{Compléments d'information:}

Hérodote rapporte la pratique de la vente aux enchères à Babylone dès le $\mathrm{VI}^{\mathrm{e}}$ siècle av. J.-C. Les Romains recouraient aux enchères dans le commerce régulier, mais aussi dans des cas particuliers, empereurs vendant du mobilier royal pour payer leurs dettes ou soldats vendant leur butin de guerre, etc.

Les deux maisons de vente aux enchères (auction houses) les plus connues sont Sotheby's (É.-U.) et Christie's (G.-B.), fondées à Londres en 1733 et en 1766 respectivement. Elles sont spécialisées dans les articles de luxe, bijoux, tableaux, etc.

t.c. entreprise de vente aux enchères (auction house, auction company)

7. Informations linguistiques:

- vendre au plus offrant: $\operatorname{sell}_{v}$ to the highest bidder

- offrir un prix, enchérir: $b i d_{v}$ on

\section{Contextes:}

Auctions are an important part of assembly and selling operations in the agricultural markets of many countries, for they have traditionnally provided a rapid and effective means of disposing of goods, especially perishable products. Auctions are also frequently used to sell products directly to the 
consumers, especially if the value cannot readily be precisely determined, as is the case of works of art or antiques. (Britannica Micropadia 1991)

Aucune formalité spéciale n'est prescrite dans les enchères de meubles. Mais, dans les adjudications d'immeubles, pour laisser aux intéressés le temps de réfléchir, le Code de procédure civile prescrit l'emploi de bougies pouvant rester allumées une minute environ. L'adjudication ne peut être prononcée qu'après l'extinction successive de trois bougies. (Grand dictionnaire encyclopédique Larousse 1987)

9. Exemples: 


\section{Appendix B}

Lexical functions mentioned in this article and other relevant lexical functions for the field of retailing

\begin{tabular}{|c|c|c|}
\hline $\begin{array}{l}\text { Lexical } \\
\text { Function }\end{array}$ & Example & $\begin{array}{l}\text { Definition (according to } \\
\text { Mel'čuk 1998; Mel'čuk et al. 1995) }\end{array}$ \\
\hline $\mathbf{A}_{\mathbf{0}}$ & $\mathbf{A}_{\mathbf{0}}($ promotion $)=$ promotionnel & adjectivization \\
\hline $\mathbf{A}_{2}$ & $\begin{array}{l}\mathbf{A}_{2}(\text { banner })=\text { under }[\text { ART } \sim] \\
\mathbf{A}_{2}(\text { franchisage })=\text { franchisé }\end{array}$ & passive adjectival \\
\hline Anti & Anti (durable good) $=$ non durable good & antonym \\
\hline $\begin{array}{l}\text { CausPred } \\
\text { Minus }\end{array}$ & $\operatorname{Conv}_{13}($ price $)=$ reduce $\sim$ & cause to become less \\
\hline Conv $_{i j}$ & $\operatorname{Conv}_{13}($ buy $)=$ sell & conversive \\
\hline Fact $_{\mathbf{i}}$ & $\begin{array}{l}\text { Fact }_{\mathbf{0}}(\text { bidder })=\sim \text { bids } \\
\text { Fact }_{1}(\text { consommateur })=\sim \text { consommer }\end{array}$ & $\begin{array}{l}\text { realize, fulfil (the requirement of) } \\
\text { when the key word is subject }\end{array}$ \\
\hline Gener & $\begin{array}{l}\text { Gener }(\text { durable good })=\text { good } \\
\text { Gener }(\text { even price })=\end{array}$ & price noun for generic \\
\hline Labor $_{i j}$ & Labor $_{12}($ banner $)=$ set up $[\mathrm{N}$ under ART ] & $\begin{array}{l}\text { do, perform (support verb when the } \\
\text { key word is indirect object) }\end{array}$ \\
\hline LabReal $_{\mathrm{ij}}$ & LabReal $_{12}($ démarque $)=/ /$ démarquer & $\begin{array}{l}\text { do, perform (support verb when the } \\
\text { key word is indirect object) }\end{array}$ \\
\hline Magn & Magn(assets) $=$ high & intense(ly), very (intensifier) \\
\hline Mult & $\begin{array}{l}\text { Mult }(\text { client })=/ / \text { clientèle } \\
\text { Mult }(\text { article })=/ / \text { assortment }\end{array}$ & collective (quantifier) \\
\hline Oper $_{i}$ & $\begin{array}{l}\text { Oper }_{1}(\text { enchère })=\text { procéder à } \sim \\
\text { Oper }_{2}(\text { enseigne })=\text { arborer } \sim\end{array}$ & $\begin{array}{l}\text { do, perform (support verb when } \\
\text { the key word is direct object) }\end{array}$ \\
\hline $\mathbf{S}_{\mathbf{0}}$ & $\begin{array}{l}\mathbf{S}_{\mathbf{0}}(\text { enchérir })=\text { enchère } \\
\mathbf{S}_{\mathbf{0}}(\text { durable })=\text { durabilité }\end{array}$ & nominalization \\
\hline $\mathbf{S}_{1}$ & $\begin{array}{l}\mathbf{S}_{\mathbf{1}}(\text { bid })=\text { bidder } \\
\mathbf{S}_{\mathbf{1}}(\text { marché aux puces })=\text { pucier } \\
\mathbf{S}_{\mathbf{1}}(\text { franchisage })=\text { franchiseur }\end{array}$ & noun for agent \\
\hline $\mathbf{S}_{2}$ & $\mathbf{S}_{\mathbf{2}}($ sell $)=\operatorname{good}$ & noun for patient \\
\hline $\mathbf{S}_{3}$ & $\mathbf{S}_{\mathbf{3}}($ licence $)=$ licencee & noun for third actant \\
\hline $\mathbf{S}_{4}$ & $\mathbf{S}_{4}($ concession $)=$ contrat de concession & noun for fourth actant \\
\hline Sing & Sing $($ clientèle $)=$ client & singulative (quantifier) \\
\hline $\mathbf{S}_{\text {instr }}$ & $\mathbf{S}_{\text {instr }}($ pallet $)=$ stacker & noun for instrument \\
\hline $\mathbf{S}_{\mathrm{loc}}$ & $\mathbf{S}_{\mathrm{loc}}($ retailing $)=$ shopping center & noun for place \\
\hline$\overline{\mathbf{S}_{\mathrm{res}}}$ & $\begin{array}{l}\mathbf{S}_{\mathrm{res}}(\text { print })=\text { printout } \\
\mathbf{S}_{\mathrm{res}}(\text { defend })=\text { acquittal }\end{array}$ & noun for result \\
\hline Syn & Syn(enchère) = offre & synonym \\
\hline $\mathbf{V}_{\mathbf{0}}$ & $\begin{array}{l}\mathbf{V}_{0}(\text { auction })=\text { to auction } \\
\mathbf{V}_{0}(\text { enchère })=\text { enchérir }\end{array}$ & verbalization \\
\hline $\begin{array}{l}\text { Magn + } \\
\text { AntiVer }\end{array}$ & Magn + AntiVer(bid) = false bidding & $\begin{array}{l}\text { intensifier + antonym of confirming } \\
\text { modifier }\end{array}$ \\
\hline Magn $^{\text {Temp }}$ & $\operatorname{Magn}^{\text {Temp }}($ good $)=$ durable & intensifier of duration \\
\hline
\end{tabular}




\section{Appendix C}

List of the 28 classes of lexico-semantic relations (LSR) and criteria of classification

\begin{tabular}{|c|c|c|}
\hline LSR & Example & Explanation \\
\hline $\mathbf{A}$ & $\mathbf{A}($ concession $)=$ concédé , concédant & adjective \\
\hline Ag & $\begin{array}{l}\mathbf{A g}(\text { enchère })=\text { enchérisseur } \\
\mathbf{A g}(\text { marché aux puces })=\text { pucier } \\
\mathbf{A g}(\text { franchisage })=\text { franchiseur }\end{array}$ & $\begin{array}{l}\text { the agent, the one who does, is } \\
\text { responsible }\end{array}$ \\
\hline But & But $($ locomotive $)=$ flux de clientèle & the aim \\
\hline Caus & $\begin{array}{l}\text { Caus (commande en souffrance) } \\
=\text { rupture de stock }\end{array}$ & causative factor \\
\hline Contrast & $\begin{array}{l}\text { Contr (bien de consommation) } \\
=\text { bien de production }\end{array}$ & contrastive or antonym \\
\hline Fonct & Fonct $($ chef de rayon $)=$ rayon & functions or responsibilities of someone \\
\hline Gener & $\begin{array}{l}\text { Gener }(\text { durable good })=\text { good } \\
\text { Gener }(\text { even price })=\text { price }\end{array}$ & noun for generic \\
\hline Instr & $\begin{array}{l}\text { Instr (saisie électronique de la } \\
\text { signature) = stylet }\end{array}$ & $\begin{array}{l}\text { instrument; object of product } \\
\text { that makes something feasible }\end{array}$ \\
\hline Loc & Loc $($ enchères $)=$ salle de vente & typical place \\
\hline Med & Med $($ mise de côté) $=$ acompte & medium, means \\
\hline Mes & Mes $($ frontale) $=$ unité de vente & measure \\
\hline Mod & $\begin{array}{l}\text { Mod(bien d'achat courant) } \\
=\text { échelle d'Aspinwall }\end{array}$ & theoretical model \\
\hline Mult & $\begin{array}{l}\text { Mult }(\text { client })=/ / \text { clientèle } \\
\text { Mult }(\text { article })=/ / \text { assortment }\end{array}$ & collective (quantifier) \\
\hline Obj & $\begin{array}{l}\text { Obj }(\mathrm{EDI})=\text { bon de commande, } \\
\text { accusé de réception }\end{array}$ & the object aimed at \\
\hline Part & Part (société mère) = succursale & \\
\hline Phase & Phase (processus d'adoption) $=$ essai & stage in a process \\
\hline Prop & $\begin{array}{l}\text { Prop (magasin minimarge) } \\
=\text { politique de prix réduits }\end{array}$ & intrinsic property \\
\hline Recip & Recip $($ publipostage $)=$ client potentiel & Recipiendary \\
\hline Result & $\begin{array}{l}\text { Result (vol à l'étalage) = perte, } \\
\text { écart d'inventaire }\end{array}$ & noun for result \\
\hline Sing & $\operatorname{Sing}($ clientèle $)=$ client & singulative (quantifier) \\
\hline Spec & Spec $($ réduction) $=$ ristourne & specific \\
\hline Strat & $\begin{array}{l}\text { Strat (distribution physique) } \\
=\text { logistique commerciale }\end{array}$ & strategy \\
\hline $\mathbf{S y n}_{\text {use }}$ & $\begin{array}{l}\text { Syn }_{\text {use }}(\text { centre de boutiques } \\
\text { spécialisées) = centre haut de gamme }\end{array}$ & variant or close synonym \\
\hline Tot & $\begin{array}{l}\text { Tot }(\text { détaillant affilié) = réseau } \\
\text { de franchise }\end{array}$ & global entity \\
\hline Util & $\begin{array}{l}\text { Util (surmontoir) = publicité sur } \\
\text { le lieu de vente }\end{array}$ & utility \\
\hline $\mathbf{V}$ & $\mathbf{V}($ code-barre $)=$ saisir, saisie de & verb or nominalisation \\
\hline $\mathbf{V}_{\text {deriv }}$ & $\mathbf{V}_{\text {deriv }}($ troc $)=$ troquer & derivative verb or nominalisation \\
\hline $\mathbf{V}_{\text {ass }}$ & $\begin{array}{l}\mathbf{V}_{\text {ass }} \text { (enchères) }=\text { vendre au plus } \\
\text { offrant }\end{array}$ & verb for associated action \\
\hline
\end{tabular}


